\title{
Personal Growth Initiative and Self-Regulated Learning in Students with Low Intelligence Potential
}

\author{
Putri Saraswati ${ }^{*}$, Tulus Winarsunu \\ Faculty of Psychology, Universitas Muhammadiyah Malang Jawa Timur 65145, Indonesia \\ *Corresponding author: psaraswati@umm.ac.id
}

Article history: Received: 11 January 2020 Received in revised form: 28 June 2020 Accepted: 10 May 2021 Published online: 09 August 2021

\begin{abstract}
Students with low intelligence potential, have limitations in academic matters. Unlike students with average intelligence, students with low intelligence will find difficulties in completing their academic tasks. Frequently, when their intelligence potentials have not been identified and are included in a regular class, they have to meet the same demands with other students who have normal/average intelligence. Therefore, they struggle to complete the given academic tasks. Their efforts to manage thoughts, feelings and behavior to achieve goals are called Self Regulated Learning (SRL). This study aims to determine the relationship of Personal Growth Initiative (PGI) and Self Regulated Learning in students with low intelligence potential. The research method used is quantitative correlational. The data collection tool used is the PGI and SRL Likert scale; the results of the filling scale are analyzed by product moment correlation statistical techniques. The results show a positive relationship between PGI and SRL $(r=0.677$, sig. 0.032) with a contribution of $45.8 \%$. The implication that can be drawn from this research is that it provides proper psychological treatment to students with low intelligence potential so that they can stay motivated in learning process.
\end{abstract}

Keywords: Personal Growth Inisiative, Self Regulated Learning, Low Intelligence.

(C) 2021 Penerbit UTM Press. All rights reserved

\subsection{INTRODUCTION}

Students with low intelligence potential in their learning will differ from those who have good intelligence. Students with good intelligence potential will usually be easy to understand the information they receive. It means they have a good understanding of lessons delivered in class. Intelligence functions are determined by intelligence tests that demonstrate skills related to academic performance (Mangunsong, 2009).

Individuals with low intelligence potential will have difficulties in understanding lessons; they will take a relatively long time in understanding the given materials. This is in accordance with a research conducted by Amelia (2016) revealing that slow learner students are slow to understand, slow in completing tasks, and low in learning achievements. Therefore, these students need clear, simple, and repetitive instructions. Their academic grades will be below the students with average or good intelligence potential. Consequently, they are often labeled as not smart enough or stupid.

Despite their difficulties, there are students with low intelligence potential who show some positive efforts in understanding lessons. They usually continue to learn and complete the tasks given by a teacher, even though the results are not as good as other students who have better intellectual potential. According to Hadi (2016), students who have below average intelligence need more time to study and struggle harder to comprehend the given materials. If they are not treated properly, they might choose not to learn because they feel unable to understand the lessons, or lack of support from the surrounding environment to learn.

In school, students are required to complete their learning tasks according to the predefined standards. It is in line with the article written by Latifah (2016) stating that, in schools, students are required to meet the minimum grades to be able to meet the standards set by the government. Thus, students with low intelligence potential who have not been identified or who are attending non-inclusion schools will automatically be exposed to these demands. These learning demands require them to perform their best efforts so that they can grow to be a better person and be ready to return to the community.

A student's effort in learning is a process of managing his own mind, feelings and behavior in learning (Zimerman in Boekaerts, Pintrich \& Zeidner, 2000); in other words, Self Regulated Learning (SRL). SRL is related with how a student can evaluate and monitor his learning, set his goals and strategies for planning, implementing, and monitoring the learning process, as well as its outcome and improvement (Winarso \& Supriady, 2016). SRL is a student's ability to manifest his wishes in a tangible manner without relying on others, meaning that he is able to study on his own by defining his effective learning methods or techniques (Octariani, 2017). In addition, he is also active in learning process (Schunk \& Zimmerman, 1998). Having good learning regulation will make students more confident, responsible and disciplined and strive to solve their own problems (Octariani, 2017). SRL has a positive influence on students' emotional intelligence and learning achievements in academic context (Winarso \& Supriady, 2016; Saraswati, 2016), while it is also associated with academic procrastination (Saraswati, 2017). 
Learning regulation is affected by various factors. According to Zimmerman $(1989,1990)$ and Winarso \& Supriady (2016), the factors that affect SRL are: 1) a student's behavior that involves self-reaction to the things that happen to him and that happens in his environment, 2) Social factors that originate from the social environment and physical environment, 3 ) individual factors, such as knowledge, goals, metacognition ability and self-efficacy. Individual or personal factors come from the inside that relate to how active a student is to continue to achieve his goals.

When someone has a clear goal and is self-regulated in learning, he will actively strive to achieve his goals. In psychological terms, it is called Personal Growth Initiative (PGI). Personal Growth Initiative is an active and intensified self-change process in one's self (Robitschek and Kashubeck, 1999; Robitschek, 2003 in Malik, 2013). PGI is an intentional individual's involvement to change and develop as a human (Robitschek in Robitschek \& Keyes, 2009). Thus, he will be active and focus on changing himself to be better, including the motivation to be a better person (Malik, 2013).

At the first stage of SRL, students with good learning regulation will analyze the tasks that will be done and motivate themselves. At the second stage, they will control and obvserve themselves. At the last stage, they will do self-reflection by giving self-judgment and will react in terms of cognitive and emotion (Boekaerts, Pintrich \& Zeidner, 2000). However, these stages are a cycle so that once the students reach the third stage, the cycle repeats and it comes back to the first or second stage. This is in accordance with the research results of Weigold, Boyle, Weigold, Antonucci, Mitchell, \& Wagar (2018) stating that students with good PGI will continue to strive to achieve their goals.

Furthermore, at the second stage of SRL, students will conduct self-control and self-observation in carrying out their plans to achieve the purpose of learning that has been established. Those who have PGI, who are actively trying to be better, will try their best to avoid distractions that may occur when they learn, and monitor themselves by observing their behavior to stay in line with the strategies that have been set to achieve the learning goals. According to Chang \& Yang (2016), good PGI makes students not easy to get distracted and remain focused on their goals to make themselves better than before.

At the third stage, students with good SRL will evaluate what they have done based on their plans, whether successful or not. It, of course, affects emotional reaction they are going to feel, whether satisfied or disappointed. So they will either change the plan in the level of SRL or continue the plan because it successfully reaches its learning goals. This is in line with the research results of Yakunina, Weigold, and Weigold (2013) arguing that individuals with good PGI will continue to strive and never give up when experiencing disruption. They will evaluate themselves and always strive to be better, which is why it is not surprising that PGI is related to students' learning regulations.

Regarding the aforementioned explanation, in this study we intend to know the relationship of Personal Growth Initiative and Self Regulated Learning in students with low intelligence potential. The result of this study is expected to contribute to the field of educational psychology, especially through a published scientific article. In addition, the practical benefit expected from this study is as a way to optimize students' learning skills, namely those who have low intelligence potential.

\subsection{LITERATURE REVIEW}

\section{Self Regulated Learning}

Self-Regulated Learning (SRL), according to Zimmerman (1989), is the level or degree of individuals' activeness in terms of metacognitive, motivational, and behavior in learning process. In other words, SRL is self-orientation feedback during learning process (Carver \& Scheier; Zimmerman in Zimmerman, 1989). Thus, SRL is a rotating process in which students are effective in their methods or learning strategies and providing responses as feedback to change self-perception, to change behavior in the learning process. SRL can also be interpreted as an activity that is realized by students to plan, implement, monitor and evaluate their learning process.

Stages and areas of SRL are 1) cognitive (thinking for the future), containing task analysis, and beliefs about self motivation, 2) Performance/will control, containing self-control and self-observation, 3) Self-reflection, containing self-assessment and self-reaction (Zimmerman in Boekaerts, Pintrich \& Zeidner, 2000). Students with good SRL will have plans for themselves, starting from analyzing the tasks to be done, setting up plans to achieve goals, and making strategies to complete the tasks at hand (Boekaerts, Pintrich \& Zeidner, 2000). In addition, they also have confidence in themselves that are used as an encouragement in completing tasks. In this case, they will have expectations of the results achieved, be goal-oriented, and have the interest to complete the tasks (Boekaerts, Pintrich \& Zeidner, 2000).

The second stage in self-regulation is controlling the will or performance, where the students control themselves by giving instructions to themselves, providing a clear picture in their minds, focusing attention on the tasks to be completed, and carrying out the planned strategies. Furthermore, they will observe their performance and even try certain things to complete the tasks. In the final stage/phase, they will conduct self-assessment by comparing themselves with their standards, or with other people (Boekaerts, Pintrich \& Zeidner, 2000). Assessing the performance, they will act on the basis of the assessment results. They will react emotionally, either feelings of pleasure and regret, then stick to the plans that have been made if they feel satisfied, or adapt to new plans if they experience disappointment.

According to Boekaerts, Pintrich \& Zeidner (2000), self-regulation can develop through observation, competition, and self-control before ultimately becomes self-regulation. Observation is to observe, or pay attention to the performance of others to be used as an example/model in completing a task. Competition refers to the way of doing things or style of a model that is emulated by the guidance of others. Self-control is the phase where the students show independence in acting according to the model skills emulated but in a structured condition. When self-regulation is formed, they are able to use skills in various conditions.

There are many factors shaping and affecting students' SRL that come from both within themselves and environmental factors. According to Bandura (1986), self-regulation is an interaction of individuals, their behavior, and their environment. This means individuals' feelings, ways of thinking and behavior will affect them in regulating themselves. The environment's role in self-regulation includes physical environment and social environment (Boekaerts, Pintrich \& Zeidner, 2000). 


\section{Personal Growth Inisiative (PGI)}

PGI is a set of skills used to develop oneself and includes one's cognitive and behavior (Robitschek, 1998), which is inherent in that person throughout his life experience (Robitschek, Ashton, Spering, Geiger, Byers, Schotts \& Thoen, 2012). PGI is a continuum, like the development process of other skills; PGI moves from low skills to skilled or high skills (Robitschek \& Hershberger, 2005). Thus, students with PGI will have various levels of skills in their lives to become better. The effort they do to become skilled in both cognitive and behavioral aspects will be different for one student to another.

Skills in self-development are different among students. There will be students who have good cognitive skills, but lack behavioral skills in developing themselves. On the other hand, there will be students who have less cognitive skills, but strong tenacity in an effort of changing themselves to be better. In different case, there will be students who have less both cognitive and behavioral skills, and vice versa. According to Ryff (Robitschek, Ashton, Spering, Geiger, Byers, Schotts \& Thoen, 2012), students who have personal growth have the spirit to continue to be better, are open to experience, realize that they have advantages, see there is progress in themselves and his behavior from time to time, and reflect on self-knowledge to change.

According to Robitschek, Ashton, Spering, Geiger, Byers, Schotts \& Thoen, (2012) there are several PGI dimensions which are used to see the level of cognitive and behavioral skills possessed by a student, namely: 1) readiness to change, 2) planning to change, 3 ) using resources to change, and 4) intensive behavior to change. Readiness and planning to change are parts of cognitive factors, while using sources to change and intensive behavior to change are behavioral factors (Borowa, Kossakowska, Harmon, Robitschek, 2018). Readiness to change is the ability of a student to identify what will change in himself (Borowa, Kossakowska, Harmon, Robitschek, 2018). Students who have good PGI will be able and aware that there are things that must change in themselves and know the things that must be changed to be better. It means they have the knowledge and awareness that they have flaws, and strengths to change those flaws. They have the ability to make plans in stages to become better (Borowa, Kossakowska, Harmon, Robitschek, 2018). They will have a detailed plan of what needs to be done to achieve a better change, not only for general purposes.

The next factor is using sources to change. Sources, in this context, are materials or human resources that can be used to change for the better (Borowa, Kossakowska, Harmon, Robitschek, 2018). In other words, resources that can help someone to change to be better, in the forms of books, classes, laptops, libraries, stationery, facilities and infrastructure, or other people, such as parents, friends, teachers, and partners. The last behavioral factor is intensive behavior to change. This refers to the skills which are used to carry out the previous stages and worked intensively (Robitschek et al, 2012; Borowa, Kossakowska, Harmon, Robitschek, 2018).

Hypotesis

There is a correlation between PGI and SRL in students with low intelligence potential.

\subsection{METHODOLOGY}

We will test the scores of free variables and bound variables using correlational statistical methods (Noor, 2011). The variables used in this study are Personal Growth Inisiative (PGI) and Self Regulated Learning (SRL).

Respondents

Population is the whole element/member of an area that is targeted to research or is the whole of the research object (Noor, 2011). The population in this study is as follows:

a. High school students

b. In Low category IQ (TIU 5 scale)

c. In Malang city

The subjects of this study are the students of one of the high schools in Malang City. The sampling technique is sampling quota, by taking up the entire population as a sample. This research procedure begins with selecting the subjects. The selection of subjects is done by providing psychological testing to check the category of the students' IQ. After the intelligence testing has been performed, we select subjects who have IQ categorized in the low category based on the TIU 5 intelligence test. Furthermore, we provide a psychological scale to the subjects of this study. The results of the statistical test obtained are used to conduct further psychological treatment to the students who have same characteristics as the research subjects.

\section{Research Instruments}

The collection of data on this research was conducted through psychological-scale provision in Likert form. Furthermore, Likert scale is used to measure variable X (PGI) and variable Y (SRL). Using the Likert scale, the subjects are going to select one of the most selfdescribed answers among the four answer options i.e. SA (Strongly Agree), A (Agree), D (Disagree), and SD (Strongly Disagree). Validity of the PGI scale is $0.314-0.609$, and reliability is 0.806 (Saraswati, 2019a). Validity of the SRL scale is between 0.310 and 0.741 with reliability of 0.943 (Saraswati, 2019b).

\section{Data Analysis}

Correlation test is used to analyze the results of research data in this study. Correlation test is used to look at the relationships between Personal Growth Initiative (PGI) and Self Regulated Learning (SRL) in students with low intelligence potential. The correlation test used is product moment. 


\subsection{RESULTS}

This study uses 10 students as subjects who meet the research population criteria: high school students who have low intelligence (TIU 5 scale) in Malang city. The average scores of PGI and SRL of these research subjects are 2.82 and 2.86. Thus, the SRL and PGI category is adequate. Statistical calculation results that shown on table 1 indicate a positive relationship between PGI and SRL $(\mathrm{r}=0$. 677, sig $=$ 0.032). The relationship between PGI and SRL can be said to be strong, as the correlation coefficient is greater than 0.5 (Santoso, 2015 ). The increasing desire and efforts of the students to be better then will relate to the increasing efforts to manage their mind, behavior, and feelings in learning process. In addition, PGI also has contribution to SRL ( $\mathrm{r}$ square $=0.458$ ). It means PGI contributes $45.8 \%$ to SRL and the remaining $54.2 \%$ comes from other factors. When looking at its SEE value, it is 0.403 , therefore the regression model produced in this study accurately predicts SRL. It is in accordance with Santoso's statement (2015): the smaller the SEE is, the more precise it is in predicting the dependent variable.

Table 1 Anova analysis

\begin{tabular}{llllll}
\hline Model & & Sum of Squares & df & Mean Square & F \\
\hline \multirow{2}{*}{1} & Regression & 1.097 & 1 & 1.097 & 6.768 \\
\cline { 2 - 6 } & Residual & 1.297 & 8 & $.032^{\mathrm{b}}$ \\
\cline { 2 - 6 } & Total & 2.394 & 9 & & \\
\hline
\end{tabular}

a. Dependent Variable: SRL

b. Predictors: (Constant), PGI

Table 2 shown the effect of PGI on SRL is significant $(\mathrm{sig}=0.032)$ of 6.768 . With a lesser significance of 0.05 , this regression model can be used to predict dependent variables (Santoso, 2015). It means that PGI affects SRL.

Table 2 Regression line

\begin{tabular}{|c|c|c|c|c|c|c|}
\hline \multicolumn{7}{|c|}{ Coefficients $^{\mathrm{a}}$} \\
\hline \multirow{2}{*}{\multicolumn{2}{|c|}{ Model }} & \multicolumn{2}{|c|}{ Unstandardized Coefficients } & \multirow{2}{*}{$\begin{array}{l}\text { Standardized Coefficients } \\
\text { Beta }\end{array}$} & \multirow[t]{2}{*}{$\mathrm{t}$} & \multirow[t]{2}{*}{ Sig. } \\
\hline & & $\mathrm{B}$ & Std. Error & & & \\
\hline \multirow{2}{*}{1} & (Constant) & .661 & .840 & & .786 & .454 \\
\hline & PGI & .753 & .290 & .677 & 2.602 & .032 \\
\hline
\end{tabular}

The equation of the resulting regression line is $\mathrm{Y}=0.661+0.753 \mathrm{X}$. In other words, if the score of the $\mathrm{X}$ (PGI) increases 1 point, then the SRL score will increase $0.661+0.753(1)$.

\subsection{DISCUSSION AND RECOMMENDATION}

Alternative hypothesis testing shows a significant result of 0.032 , that PGI has a positive relationship to SRL ( $\mathrm{r}=0.677)$ and has a contribution of $45.8 \%$. This research shows that the higher the student's PGI is, the more increasing the student with low intelligence potential's SRL is. This can be explained by the description that SRL is a student's ability to manage his mind, behavior and feelings in achieving learning objectives (Zimerman in Boekaerts, Pintrich \& Zeidner, 2000). Moreover, SRL is how a student plans, executes, and evaluates the learning process and the outcomes (Garrido-Vargas, 2012; Boekaerts, Pintrich \& Zeidner, 2000). Thus, when a student conducts self-regulation in learning, he is going through 3 phases/stages.

According to Zimerman (Boekaerts, Pintrich \& Zeidner, 2000), the stage is a cycle. Starting from a cognitive stage, the student analyses the task he has in learning and motivates himself to achieve a set goal. In analyzing the task, he will determine the goals/targets that will be achieved in learning process and create a learning strategy. Furthermore, in doing self-motivation, he must have confidence in his abilities. The more confident he is about the goals that will be achieved, the better the SRL will be and the more related it is to the learning strategy used (Schunk \& Schwartz, 1993; Zimmerman, Bandura, \& Martinez-Pons, 1992 in Boekaerts, Pintrich \& Zeidner, 2000). Furthermore, self-motivation in the SRL stage also includes the expectation of achieved results, value/interest from the self, and orientation to the objectives (Boekaerts, Pintrich \& Zeidner, 2000). The more he has the desire and effort to be a better person (PGI), the stronger the expectation of the result he has set in learning will be. This is in accordance with the research results of Robitschek (2012) and Yakunina, Weigold, \& Weigold (2013) stating that students with good PGI will be good in planning and open to experience.

The next stage, the student will carry out the plans he has made in the first stage. This stage consists of self-control and selfobservation (Boekaerts, Pintrich \& Zeidner, 2000). Self control can be self instruction, imagery, focusing attention on task and learning strategy. It aims to help students in minimizing existing distractions and completing tasks optimally. A student with good PGI will strive intensely to develop himself so that he will be stronger in controlling himself and will not be easily distracted in learning. This is in line with the research results of Yakunina et al. (2013), stating that PGI is associated with someone's ability to adapt with stress. This means that when a student has a good PGI, he tends to have good adaptability to stress, and he is not easy to be distracted. According to Chang \& Yang (2016) students with PGI will remain consistent and focus on their goals to be better.

In the second stage of SRL the individual performs observations against himself. This self-observation is done by recording or note taking specific things from his performance, environmental conditions, and performance and environmental effects (Zimmerman \& Paulsen, 1995 in Boekaerts, Pintrich \& Zeidner, 2000). Good PGI will lead him more thorough in observing what happens to himself and his environment, especially with respect to the targets he has set. His PGI capability also relies on the culture and neighborhood wherein he lives. This is in accordance with the research of Robitschek (2003), stating that individuals' PGI levels differ in each culture, including their awareness and intention to be better. 
At the final stage the student will reflect on what was done in the second stage. At this stage, he will assess the performance and evaluation. The assessment is related to cognitive and emotional reflections. This assessment affects his emotion so that he will respond to it in the next planning, that is in the first stage. Some students will change their plans. However, there are some who will still stick to the plan that has been made in the beginning because they have positive reflection on the emotions and the outcome of their learning (Boekaerts, Pintrich \& Zeidner, 2000). At this rate, according to Weigold et al. (2018), students with good PGI are ready to change for the better.

It is clear that when a student has the desire and effort to always develop and change for the better, he will strive actively to become more optimal in obtaining his objectives through a learning regulation process. It goes the same with students who have low intelligence potential. Although they are slow learners, they will eventually be able to manage his mind, behavior and feelings in achieving his learning goals as long as they have the desire to develop and to be better. Based on the aforementioned explanation, it can also be seen that there are other factors that affect SRL in students with low intelligence potential, such as family support (social environment), learning facilities/media (physical environment), self-confidence, self efficacy, etc. (Boekaerts, Pintrich \& Zeidner, 2000).

\subsection{CONCLUSION}

The higher the desire and effort of students to be better are, the better their ability to regulate themselves in learning is. This also applies to students with low intelligence. They will try to plan their learning process, carry out the plan and reflect on what they have achieved given the limited ability and understanding as students with low intelligence potential.

The results of this study are expected to be able to help educational psychologists and educators to be more intensive and creative in assisting and guiding students with low intelligence potential, so they can achieve their full potential in learning process. As for students, reflecting on the results of this study, it is expected that they can be more excited to learn and seek for help from friends, teachers, or mentors in learning process in order to make their potential grow optimally. As for the next researchers, it is expected that they will be able to provide more accurate research by employing more measuring instruments to analyze the correlation between PGI and SRL, not only limited to the use of psychological scale in the form of statements.

\section{References}

Amelia, W. (2016). Karakteristik Dan Jenis Kesulitan Belajar Anak Slow. Jurnal Ilmu Kesehatan Aisyah 1(2), 53-58.

Bandura, A. (1986). Social Foundation of Thought and Action: A Social Cognitive Theory. Englewood Cliffs, NJ: Prentice-Hall

Borowa, D., Kossakowska, M.M., Harmon, K.A., Robitschek, C. (2018). Personal Growth Initiative's to Life Meaning and a Satisfaction in a Polish Sample. Current Psychology. 39, 1648-1660.?doi:10.1007/s12144-018-9862-2

Boekaerts, Monique, Pintrich, Pul R., \& Zeidner, Moshe. (2000). Handbook of Self Regulation. London: Academic Press.

Chang, E.C., \& Yang, H. (2016). Personal and Family Growth Initiative As Predictors of Study Engagement in Chinese and American College Students: Is There any Evidence for Group Differences? PAID, 102, 186-189. doi:10.1016/j.paid.2016.07.004

Garrido-Vargas, M. (2012). Relationship of Self-Regulated Learning and Academic Achievement Among English Language Learners. (Doctoral dissertation, the University of Arizona).

Hadi, F.R. (2016). Proses Pembelajaran Matematika pada Anak Slow Learners. Premiere Education, 6(1), 55 - 41

Latifah, T.N. (2016). $\quad$ Fenomena $\quad$ kkm. $\quad$ Kompasiana 23 maret 2019 . Diperoleh https://www.kompasiana.com/trisnianurul/56faaf1c85afbd5105b5ab5b/fenomena-kkm\# Retrieved date: 30 December 2019

Malik, N. I. (2013). Personal Growth Initiative and Self Esteem As Predictors of Academic Achievement Among Students of Technical Training Institutes. Pakistan Journal of Social Sciences, 33(2), 435-446.

Mangunsong, Frieda. (2009). Psikologi dan Pendidikan Anak Berkebutuhan Khusus Jilid Satu. Jakarta: LPSP3 UI.

Noor, J. (2011). Metode Penelitian Skripsi, Tesis, Disertasi \& Karya Ilmiah. Jakarta: Kencana Prenadamedia Group.

Octariani, D. (2017). Self Regulated Learning Dalam Pembelajaran Matematika. MES (Journal of Mathematics Education and Science), 2(2), 10-16.

Robitschek, C. (1998). Personal Growth Initiative: The Construct and Its Measure. Measurement and Evaluation in Counseling and Development 30, 183-198.

Robitschek, C. (2003). Validity of Personal Growth Initiative Scale Scores with a Mexican American College Student Population. Journal of Counseling Psychology, 50(4), 496-502. doi:10.1037/0022-0167.50.4.496

Robitschek, C., \& Hershberger, A.R. (2005). Predicting Expectations About Counseling: Psychological Factors and Gender Implication. Journal of Counseling and Development, 83, 457 - 469. doi:10.1002/j.1556-6678.2005.th00367.x

Robitschek, C., \& Keyes, C.L.M. (2009). Keyes's Model of Mental Health with Personal Growth Initiative as a Parsimonious Predictor. Journal of Counseling Psychology, 56(2), 321-329. doi:10.1037/a0013954

Robitschek, C., Ashton, M.W., Spering, C.C., Geiger, N., Byers, D., Schotts, G.C., \& Thoen, M.A. (2012). Development and Psychometric Evaluation of the Personal Growth Initiative Scale-ii. Journal of Counseling Psychology, 59(2), 274-287. doi:10.1037/a0027310

Santoso, S. (2015). SPSS20 Pengolahan Data Statistik di Era Informasi. Jakarta: PT. Alex Media Komputindo, Kelompok Gramedia.

Saraswati, Putri (2016). Kontribusi Self-Regulated Learning dan Kecerdasan Emosi Dalam Konsentrasi Belajar. Jurnal Psikologi Perseptual, 1(2), 102-120.

Saraswati, Putri. (2017). Strategi Self Regulated Learning dan Prokrastinasi Akademik Terhadap Prestasi Belajar. Intuisi, 9(3).

Saraswati, Putri. (2019a). Goal Achievement as a Predictor of Personal Growth Initiative for Generation Z. Advances in Social Science, Education and Humanities Research (ASSEHR), 304.

Saraswati, Putri. (2019b). Kemampuan Self Regulated Learning Ditinjau dari Achievement Goal dan Kepribadian pada Remaja di Kota Malang. Indigenous, 4(2),6978. doi: 10.23917 /indigenous.v4i2.7209

Schunk, D.H., \& Zimmerman, B.J. (1998). Self-regulated Learning: From Teaching to Selfreflective Practice. New York, NY: Guilford Press

Weigold, I.K., Boyle, R.A., Weigold. A., Antonucci, S.Z., Mitchell, H.B., \& Martin-Wagar, C.A. (2018). Personal Growth Initiative in the Therapeutic Process: An Exploratory Study. The Counseling Psychologist, 46, 481-504. doi:10.1177/0011000018774541

Winarso, W., \& Supriady, D. (2016). Menilai Prestasi Belajar Melalui Penguatan Self Regulated Learning dan Kecerdasan Emosional Siswa pada Pembelajaran Matematika. Jurnal Didaktik Matematika, 3(2), 54-66.

Yakunina, E.S., Weigold, I.K., \& Weigold, A. (2013). Personal Growth Initiative: Relations with Acculturative Stress and International Student Adjustment. International Perspectives in Psychology: Research, Practice, Consultation, 2(1), 62-71. doi:10.1037/a0030888

Zimmerman, B.J. (1989). A Social Cognitive View of Self-Regulated Academic Learning. Journal of Educational Psychology,81(3), 329-339.

Zimmerman, B.J. (1990). Self-Regulated Learning and Academic Achievement: An Overview. Journal of Educational Psychology,25(1), 3-17. 